研究

基板付けした皘層セラミックコンデンサのたわみ強度に関する構造的要因の影響

\author{
佐藤 真一, 五十嵐克彦, 神谷 貴志, 野村 武史 \\ TDK 磁材料研究所, $\mathbf{T} 286$ 成田市南羽鳥字松ヶ下570-2.
}

\title{
Effect of Structural Factors on the Bending Strength of Multilayer Ceramic Capacitors Mounted on the Printed Circuit Board
}

\author{
Shinichi Sato, Katsuhiko Igarashi, Takashi Kamiya and Takeshi Nomura \\ Materials Research Center, TDK Corporation, 570-2 Aza-matsugashita Minami-hatori, Narita 286.
}

Received January 17, 1995

\section{SYNOPSIS}

The effect of structural factors on the bending strength of multilayer ceramiccapacitor (MLC) monuted on a printed circuit board has been studied, with specialreference to the termination electrodes of MLC. Capacitance of MLC suddenly decreases duringthe bending test. This decrease is caused by the breakage of the ceramic body whichinitiated at the edge of the termination electrodes. It is also shown that theamount of the solder, the shape of termination electrodes, and the bending strength of ceramicbody are the important factors. FEM analysis supported the results. Furthermore, the fluctuation of the bending strength was affected by the position of MLC on the board.

KEY WORDS

Bending strength, solder, termination electrodes.

\section{1. 緒 言}

表面実裝技術(SMD)の進展に伴い，電子部品には軽 薄短小化及び高密度実装が要求されている，表面実 装部品(SMD)には，積層セラミックコンデンサ，樌層 チップインダクタ及びこれらを一体化した積層 L C フィルタ等が知られているが，中でも積層セラミッ クコンデンサは, $2.0 \mathrm{~mm} \times 1.2 \mathrm{~m}$ 17ー $\rightarrow 1.0 \mathrm{~mm} \times 0.5 \mathrm{~mm}$ 多17゚前実にダウンサイジング 化が進んでいる，それに伴い実装の信頪性（耐熱衝 慗性に優れ，たわみ强度，固着強度の向上，更に強 度値のばらつきの抑制），特にたわみ強度の強いこ とが求められており，この強度の向上のために種々
の検討がなされてきた1，2）。しかしながら，多くの 研究報告が強度向上技術に関して述べているのみで， 実装時に重要な強度值ばらつきについての検討がな されていない，そこで本研究では，たわみ強度向上 及び强度值ばらつきに関して, 積層セラミックコン デンサ（チップ）の構造的要因の影響について険討 を行った。

\section{2. 実験方法}

たわみ強度試験方法をFig.1に示す，端子電極を形 成した積層セラミックチップコンデンサ（2012タイ プ）をメタルマスクを用いてはんだ量を一定に制御 
し,ガラスエポキシ基板にリフロー炉 $\left(220^{\circ} \mathrm{C}\right)$ では んだ付けを行った。この基板の裏面から $1 \mathrm{~mm} / \mathrm{s}$ 速度 で加圧し，JIS C 6429に従って積層セラミックコン デンサの静電容量が- $12.5 \%$ 低下した時点の基板の変 位量をたわみ量とし、これをたわみ強度とした，ま た, チップの破壞モードについてはSEMで解析を行っ た.さらに, 有限要素法 (FEM) 解析でたわみ強度試 験の際にチップに生じる応力について調べた。

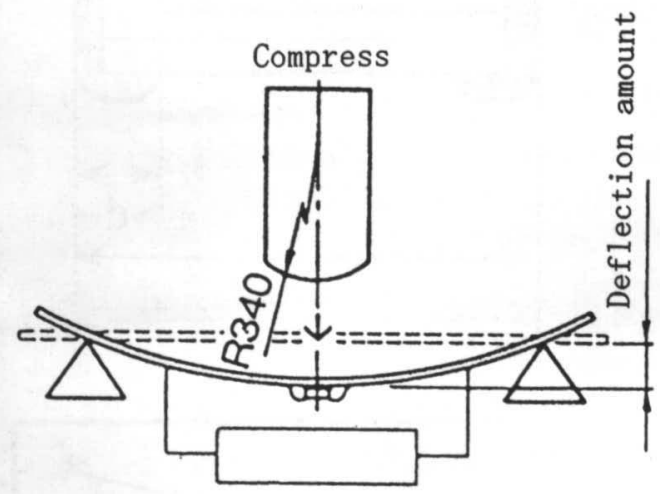

Impedamce analyzer

Fig. 1 Schematic diagram of the deflection test.

\section{3. 結果及び考察}

\section{1 破壞モード解析}

たわみ強度試験後のチップの破壊面をFig.2に示す。 チップにクラックが生じており, 内部電極を破断し ていることが分かる.このクラックによってチップ の静電容量が低下する.

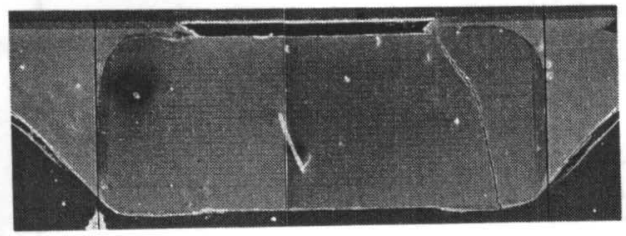

Fig. 2 Secondary electron microscopic image of the mode $\mathrm{A}$ destruction in the multilayer ceramiccapacitors.

そこでたわみ強度試験時にチップに生じる応力をFEM を用いて 2 次元の弾性解析で調べた. 基板表面から 荷重を $5 \mathrm{~kg}$ 加えた時の, チップの端子電極エッジ部分 に生じる応力分布をFig.3に示す．基板側に配線され
た端子電極エッジ部分の素地周辺に引張り応力が集 中していることが分かる、したがって，この箇所を 起点に破壤が生じ, チップ内部へクラックが派生し たものと考えられる. また,ここにはデータを示さ ないが, 端子電極エッジ部分の素地付近からクラッ クが発生し, チップ内部で止まっているものも確認 された.このことからもクラック発生起点が, 端子 電極エッジ部分の素地周辺であることを示唆してい る. 以降FEMではこの箇所の応力を求めた.

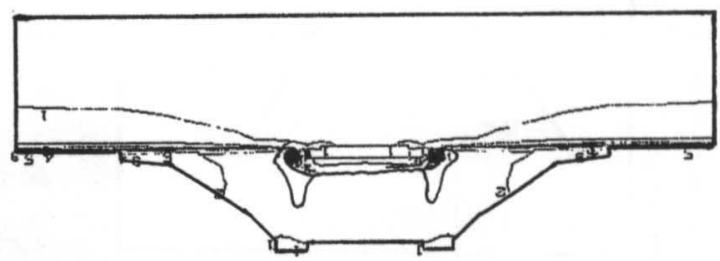

Fig. 3 Diagram of FEM analysis.

\section{2 はんだ量とたわみ強度の関係}

チップのたわみ強度を測定する際, メタルマスク を用いてはんだ量を一定に制御し，ガラスエポキシ 基板にチップをはんだ付けする，このときのはんだ 量は，チップのサイズによって変更される，そこで はんだ量を変えた時のたわ強度の変化を調べた。 Fig.4(A)の方法にて端子電極の厚みを含むチップの 厚みをaとして，はんだの量を変えたときのランド からの厚みを $\mathrm{b}$ とした場合, b/aにて求めた值をはん だ量とした、結果をFig.4(B) (C)に示す。なお，以後 チップに生じる応力をので示す，はんだ量が1.0付近 である場合, たわ強度が最も大きくなり，これは FEMの結果と一致していることが分かる、はんだ量が 0.1と1.5の時を比較した場合, たわみ強度及びチッ プに生じる応力は同程度である.しかしながら、こ れはチップにクラックが発生しないと仮定した場合 の残留応力であり, 実際の破壞モードは，はんだ量 が0.10場合, 主としてはんだと端子電極間で剥離が 生じ静電容量が低下する. それに対して, 1.50場合, チップの破壊によって静電容量が低下する。した がって, 1.0未満のはんだ量の場合には, 実際にチッ プに生じる応力は, Fig.4(C)に示した值よりも小さ くなるものと考えられる. 


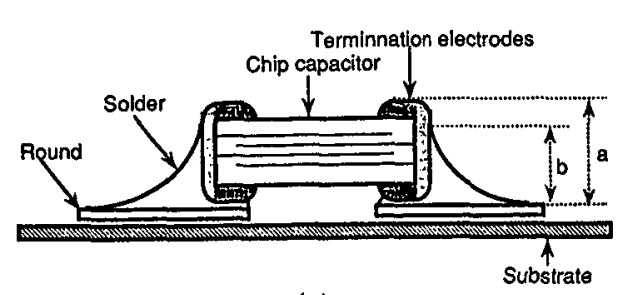

(A)

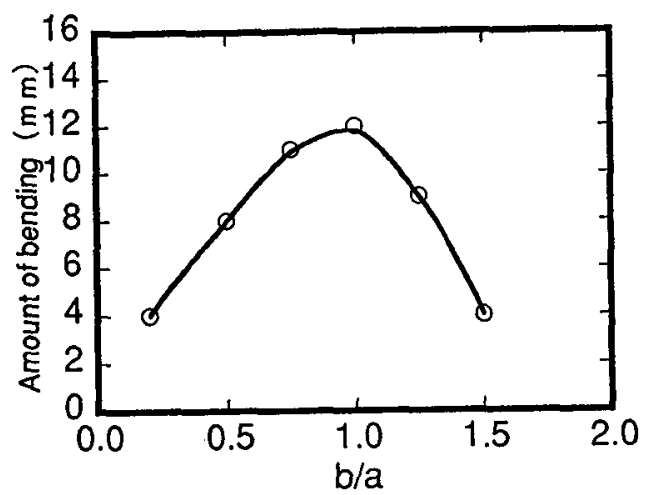

(B)

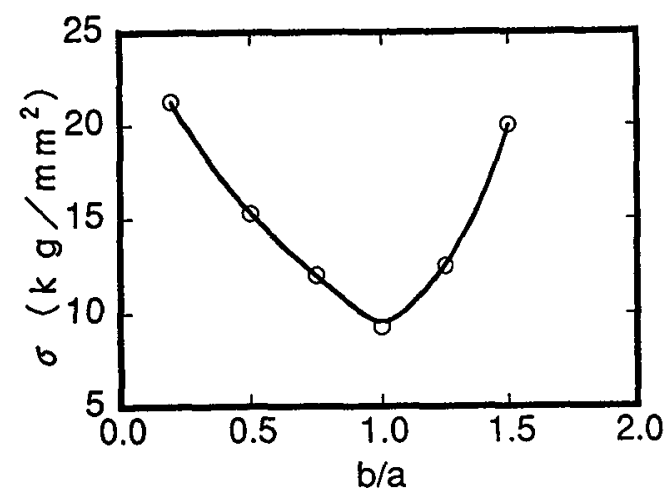

(C)

Fig. 4 Relationship between the amount of solder and the bending strength.

\section{3 端子電極形状とたわみ強度の関係}

端子電極は通常電極ぺーストを叙布することに よって形成されるが，チップのサイズあるいは, チップの材質によって端子電極形状が変更される. そこで端子電極形状とたわみ強度の関係を調べた。 Fig.5(A)に示す方法にてチップの長さを2cとして，

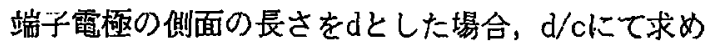
た値を側面電極寸法比としたははんだ量は3.2で最も 強度の大きかった量で行った，Fig.5(B)(C)に端子電 極形状とたわみ强度の関孫の結果を示す，側面電極 寸法比が大きくなるに従い，たわ強度が大きくな
ることが分かる。これは側面電極寸法比が大きくな るに従い，チップに生じる応力が減少するFEMの結果 と一致した。
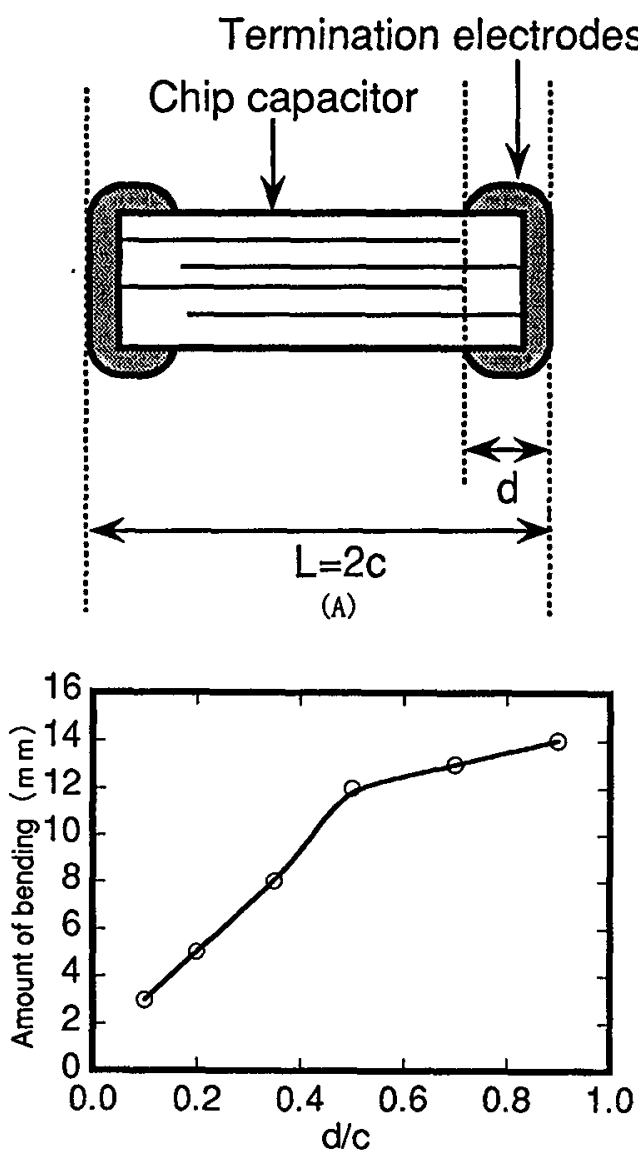

(B)

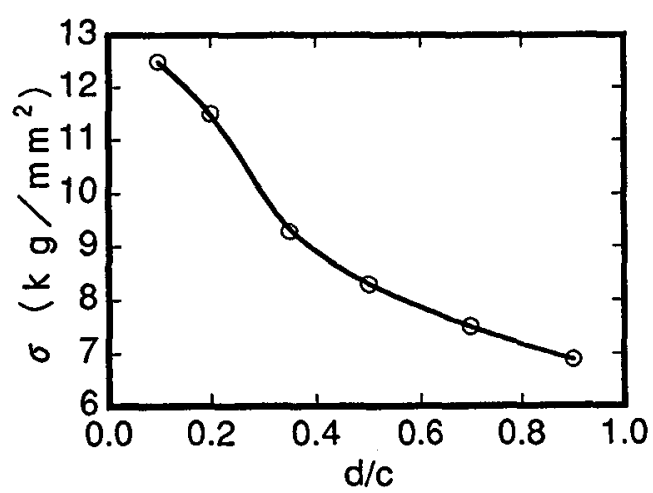

(c)

Fig. 5 Relationship between dimensions of termination electrodes and the bending strength. 


\section{4 チップの素地強度とたわみ強度の関係}

素地内部が破壤されることからチップの素地強度 がたわみ強度に影響を及ぼすことが考えられた。 そ こで, チップの焼成温度を変えることによって素地 強度を設定した，素地強度は抗折強度とした，チッ プの素地強度とたわみ強度の関係の結果をFig.6に示 す. 抗折強度が向上するに従い，たわみ強度が向上 していることが分かる、これまでの結果から，たわ 強度試験の際にチップに生じる応力が $9 \mathrm{~kg} / \mathrm{mm} 2$ 程度 あることから，素地強度がそれ以上の強度を有する 必要があることを示しているものと考えられる，な お, 素地の焼成温度が変化することによって端子電 極中のガラスとの反応 3 ) の程度が変化するものと考 えられるが本実験では考虑しなかった。

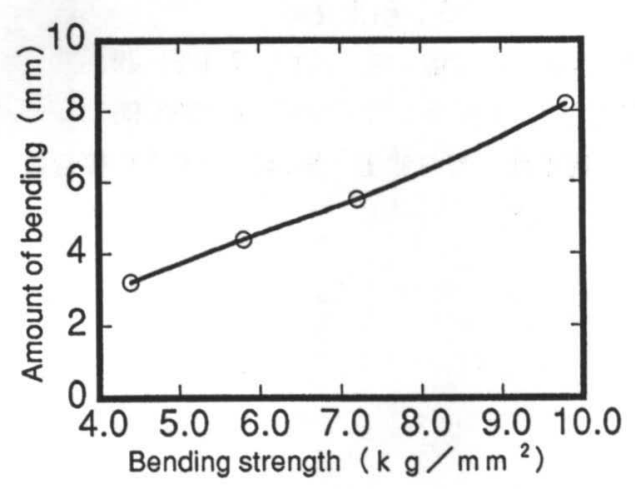

Fig. 6 Relationship between the bending strength and the deflection strength.

\section{5 たわみ強度值のばらつき}

はんだ量, 端子電極形状, 及び素地強度を一定に しても，たわ強度は非常にばらつきを生じやすい， そこで, 強度值のばらついたチップのたわみ強度試 戨後の破壊モードを調べた，結果をFig.7に示す．大 半の破懐は $(\mathrm{A})$ に示すように, 基板側の端子電極の エッジ部分の素地付近から反対の端子電極へクラッ クが生じている，これに対して，たわみ強度が平均
に対して大小両極端にばらつく場合は, (B)に示すよ うに，端子電極／素地界面にクラックが到達してお り, 破壊の起点も端子電極のエッジ部分の素地付近 ではないことが分かる，また，チップが基板中心に 対してずれを生じている，そこで，このチップの中 心ずれの量とたわ強度の関係を調べた，Fig.8(A) に示す方法にて両端子電極の表面から基板のランド 端までの長さをそれぞれとり，長い值をf，短い值を eとした場合，f-eから求めた值をランド差とした. この結果をFig.8(B)をに示す. ランド差が大きくな るに従い，たわ強度が大きくばらつくことが分か る. 端子電極はランド部で基板と接着しており, た わみ強度試験は基板中央から加圧することから，ラ ンド部及びチップに不均一な応力が生じるものと考 えられる.その結果，Fig.7(B)に示したようなク ラックが発生したものと考えられる，したがって， 強度値のばらつきを抑制するためには, ランド差す なわちチップの中心ずれを極力低滅することが必要 である.

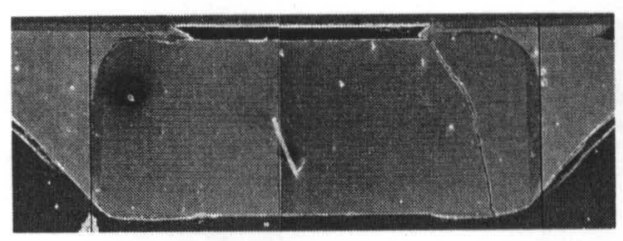

(A)

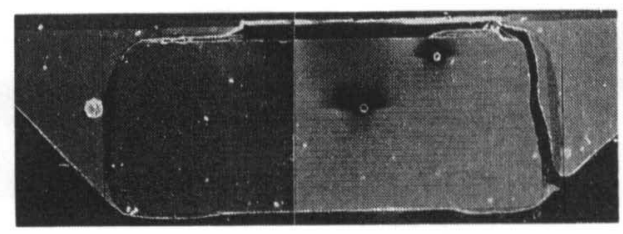

(B)

Fig. 7 SEM images of the multilayer ceramic capacitors after bending test. 


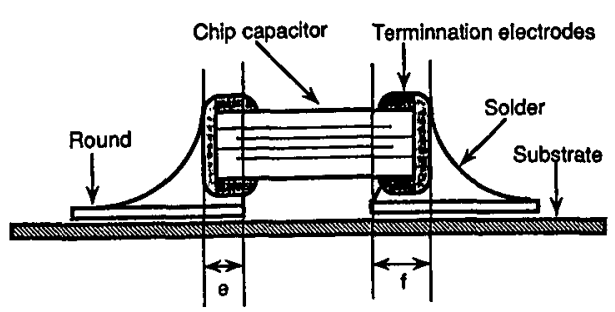

(A)

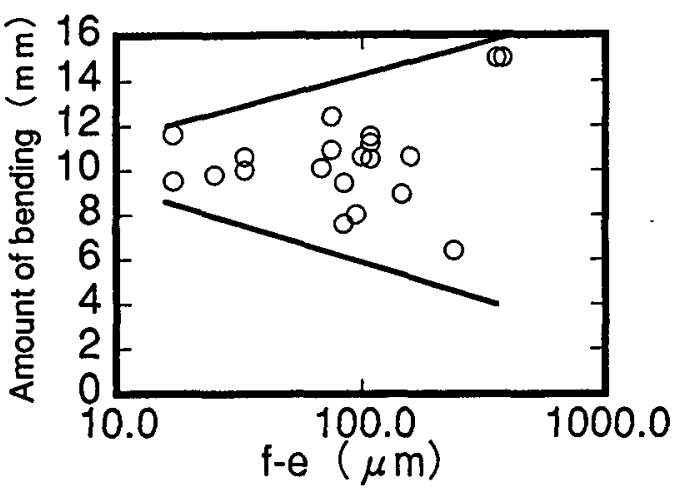

(B)

Fig. 8 Relationship between the differential of rounds and the bending strength.
4. まとめ

積層セラミックコンデンサのたわみ強度に及ぼす 構造的要因の影響を検討した結果，以下の知見が得 られた。

（1)たわみ強度訊験時には，端子電極エッジ部分の素 地付近に引張り态力が集中し，この籄所を起点にク ラックが生じる.

(2)たわみ強度ははんだ量に強く影響され，たわみ強 度が最大となるはんだ量が存在する。

(3)端子電極形状が大きくなるに従い，たわみ強度は 大きくなる。

(4)チップの抗折強度とたわみ強度に相関が認められ た.

（5）チップの基板への取り付け位置が中心からずれる ほど,たわみ強度值はばらつく。

\section{5. 引用文献}

1）鎌田信雄，大阪猛：電子技術，7 199179 .

2）鎌田信雄，大阪猛：電子技術，81993 96.

3）五十嵐克彦, 野村武史 : 第38回マイク口接合委 員会資料，1993,1. 